\title{
Comprehending conventional and novel metaphor processing: A reaction time study
}

\author{
Mohammad Reza Khaleghi'" (iD, Yahya Keikhaie², Mahdi Tehrani Doost ${ }^{3,4}$, Ramin Golshaie ${ }^{5}$
}

1. PhD Student of Linguistics, Department of English Language and Literature, Sistan and Baluchestan University, Zahedan, Iran

2. Assistant Professor of Linguistics, Department of English Language and Literature, Sistan and Baluchestan University, Zahedan, Iran

3. Professor of Psychiatry and Cognitive Neuroscience, Research Center for Cognitive and Behavioral Sciences, Tehran University of Medical Sciences, Tehran, Iran.

4. Institute for Cognitive Science Studies (ICSS), Tehran, Iran

5. Assistant Professor of Linguistics, Alzahra University, Tehran, Iran

Recieved: 20 Aug. 2018

Revised: 1 Jan. 2019

Accepted: 8 Jan. 2019

\section{Keywords}

\section{Reaction time}

Conventional and Novel metaphors

Literal/Nonliteral language processing

\section{Corresponding author}

Mohammad Reza Khaleghi, PhD Student of Linguistics, Department of English Language and Literature, Sistan and Baluchestan University, Zahedan, Iran

Email: Mohammadrkhaleghi@gmail.com

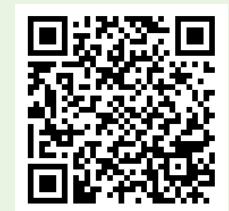

\section{Abstract}

Introduction: The processing of metaphors in comparison with literal sentences has attracted many scholars from various fields, including linguistics, psychology, and cognitive neuroscience. The present research, aimed to investigate the processing of literal sentences and metaphors (conventional and novel) in Persian language.

Methods: A reaction time task used to determine how literal sentences and metaphors are processed. For this purpose, four hundred sentences sentences in four types of expression: conventional and novel metaphors, anomalous, and literal sentences (each contains one sentences) were constructed. Reading the sentences, subjects were asked to determine the comprehending amount of meaning of the sentences (from 0 to 3 ) by pressing the corresponding key on the keyboard. The answers were recorded by EEGLAB. The reaction time data were analyzed using repeated measurement (ANOVA) and the pairwise comparison method in four expressions.

Results: The pair-wise comparison of the response time showed that literal sentences faster than conventional metaphors and conventional metaphors faster than novel metaphors are processed.

Conclusion: According to the obtained findings, it can be concluded that different mechanisms are involved in the processing of literal sentences and metaphors. Conventional and novel metaphors can be processed through a continuum of a single mechanism like conceptual mapping. In this mechanism, novel metaphors through analogy and conventional metaphors through categorization are understood. The processing of literal sentences, conventional and novel metaphors can also be explained through a continuum of saliency and expectancy. 


\section{درك استعار ههاى متعارف و استعار ههاى بديع: يك مطالعه زمان واكنش

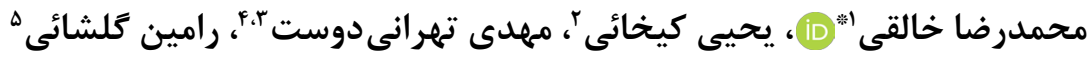

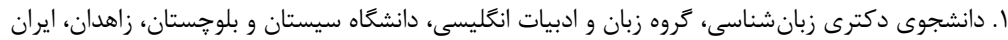

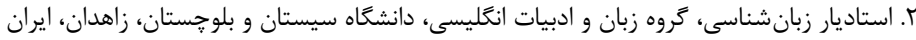

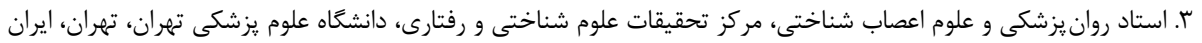

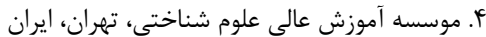

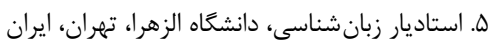

\section{ars}

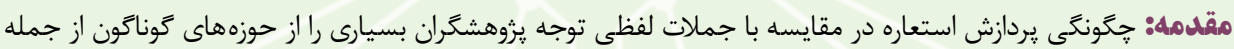
زبان شناسى، روانشناسى و علوم اعصاب شناختى به خود معطوف داشته است. در يُوهش حاضر نحوه يردازش جملات لفظى و استعارهها (متعارف و بديع) در زبان فارسى مورد بررسى قرار گرفت. روش كار: از يك تكليف زمان واكنش براى تعيين جَّونكى درك جملات لفظى و استعاره ها استفاده كرديد. بدين منظور جهارصد جمله (در f وضعيت لفظى، استعارى متعارف، استعارى بديع و بى معنى هر كدام صد جمله) ساخته شد. آزمودنى ها در حين خواندن جملات و به هنعام درك جملات مورد نظر معنى آن را (از • تا س) با فشار دادن كليد مربوطه روى صفحه كليد مشخص كردند. پاسخ آزمودنىها توسط نرم فزار EEGLAB ثبت كرديد. دادهاى زمان واكنش با استفاده از تحليل واريانس با اندازه كيرى مكرر و مقايسه دو سويه دادها در جهار وضعيت مورد تجزيه و تحليل قرار كرفت. يافته ها: مقايسه دوسويه زمان واكنش نشان داد كه جملات لفظى نسبت به جملات استعارى متعارف و جملات استعارى رل رد رد متعارف نسبت به جملات استعارى بديع سريعتر پردازش مى شوند. نتيجه كَيرى: با توجه به يافتههاى فوق مى توان نتيجه كرفت كه مكانيسمهاى متفاوتى در ثردازش زبان لفظى و استعارى شركت دارند. بردازش استعارههاى متعارف و بديع نيز مى تواند از طريق پييوستارى از يك مكانيسهم واحد مانند نحاشت مفهومى صورت يذيرد. در اين مكانيسم پِيوستارى استعارهاى بديع به صورت مقايسه فهميده مى شوند و استعارههاى متعارف به صورت مقولهبندى فهميده مىشوند. با توجه به يافته هاى فوق همجنين مى توان فرايند درى جملات لفظى، استعارى متعارف و بديع را بر روى بيوستارى از برجستگى و قابل انتظار بودن تبيين كرد.

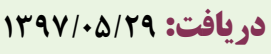

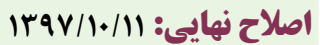

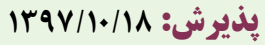
وازههاى كليدى زمان واكنش استعارههاى متعارف و بديع يردازش زبان لفظى اغير لفظى

\section{نويسنده مسئول}

محمدرضا خالقى، دانشكده ادبيات و علوم انسانى، گروه زبان و ادبيات انخليسى، دانشگاه سيستان و بلوجّتان، زاهدان، ايران

ايميل:Mohammadrkhaleghi@gmail.com

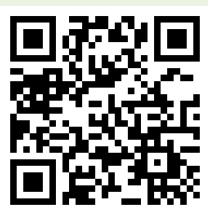

doi doi.org/10.30699/icss.21.3.120

مقلdمه

به يك محرك كفته مىشود. دشوارى، آشنايى و قابل انتظار بودن محرك روى زمان واكنش تاثير مى گذارند. هرجه يك محرك دشوارتر باشد اطلاعات بيشترى يردازش مى شود و در نتيجه فرايند يردازش به زمان بيشترى نياز خواهد داشت. در مقابل هرجه يك محرك آشناتر باشد، اطلاعاتى كه بايد پردازش شود كمتر است و هرجه اين اطلاعات
تكليف زمان واكنش (Reaction time) يكى از تكليف هاى متداولى است كه به هنگام بررسى فرايندهاى دخيل در درك استعاره (Metaphor) كفته مى شود كه بين ادراك يك محرك و ياسخ به آن محرك صرف رف ره مى شود. به عبارت ديخر زمان واكنش به توانايى ادراك، يردازش و پاسخ 
روساختى استعاره مفهومى زير ساختى "بحث به مثابه جنَت" است و با استفاده از نگاشت مفهومى (Conceptual Mapping) بين حوزهاى بين بحث و جنَ قابل درك مى گردد. اين نگاشت از مجوعه ثابتى از استعارههاى مفهومى تشكيل مى گردد. وقتى يك عبارت استعارى به كار مىرود نحاشت مفهومى فعال مى شود و بدين ترتيب مى توانيم با استفاده از جنَ در مورد بحث بيانديشيم. استعارهها دو دسته اند، استعارههاى متعارف كه عضو ثابت نظام مفهومى اند و استعارههاى بديع كه تازه ابداع شدهاند و كاربرد عام ييدا نكرده-اند و تعبير آن به تلاش بيشتر نياز دارد (^). Lakoff بر اين باور است نظريه استعاره مفهومى از يك طرف با ديدگاه دسترسى غيرمستقيم و از طرفى ديگر با ديدگاه دسترسى مستقيم همسو است (9). معنى استعارههاى بديع به طور غيرمستقيه (مقايسه) و معنى استعارههاى متعارف به طور مستقيم (مقوله بندى) در دسترس قرار مى خيرند.

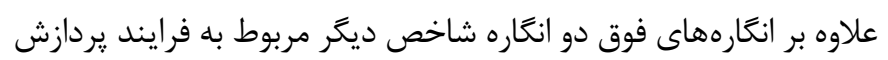
استعاره عبارتند از انگًاره برجستخى مدرج (Gradient Salience Model) Giora و Bowdel اين نكاشتهاى مفهومى يا استعارى بودن نيست كه سرعت درك را تعيين مى كند بلكه "برجستخى " عبارتهاى زبانى است كه اين نقش را به عهده دارد. اين انگاره پيشنهاد مهى كند كه سرعت درك براى استعارههاى متعارف برجسته و عبارتهاى لفظى بايد يكسان باشد اما استعارههاى متعارف بايد سريعتر از استعارههاى بديع غير برجسته درك شوند. انعاره دوم يك جارجوب نظرى واحد است كه سعى دارد بين نظريات انگارههاى مقايسه سنتى يردازش استعاره و انگارههاى مقولهبندى آشتى برقرار كند به عبارتى انواع انغارههاى مشاهده شده در مطالعات يردازش استعاره را يكجا در يك الگوى شناختى گرد آورده معه است. انگاره دوره استعاره فرايند درك استعاره را اين گونه تبيين مى كند وقتى كه يك استعاره بديع است به صورت مقايسه فهميده مىشود و وقتى كه متعارف مىشود به صورت مقولهبندى فهميده مىشود. در ادامه يزوهشهاى ايرانى و غير ايرانى كه از تكليف زمان واكنش در مطالعه يردازش استعاره بهره بردهاند را مرور مى كنيم.

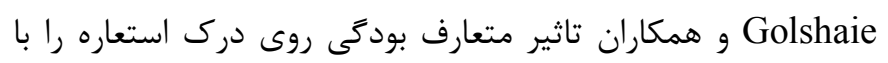
استفاده از ييكره زبانى (•ه ميليون وازهاى) مورد مطالعه قرار دادند

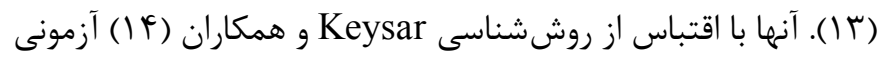
را طراحى كردند كه حاوى سه دسته سناريو: سناريو حاوى استعاره متعارف، سناريو حاوى استعاره غيرمتعارف، سناريو غيراستعارى بود. يك جمله واحد يس از هر سناريو تكرار مىشد. استدلال آنها اين بود
كمتر باشد زمان واكنش سريعتر خواهد بود. زمانى كه منتظر ديدن يا شنيدن محرك خاصى هستيد اين زمان واكنش حتى كمتر خواهد بود. يزوهش هاى يردازش استعاره با استفاده از تكليف زمان واكنش عمدتا بر مبناى يكى از دو رويكرد كلى دسترسى غيرمستقيم و دسترسى مستقيم

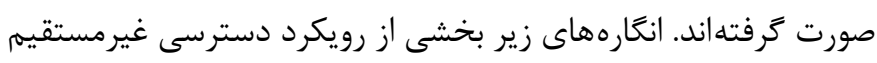
به شمار مىروند. بر اساس انگاره كاربرد شناسى معيار Grice (1) و Searel از مكانيسمهاى درك زبان لفظى متفاوت است و محاسبه معنى لفظى قبل از محاسبه معناى استعارى صورت مى گيرد. طبق انعاره نابرابرى برجستخى (Ortone (Salience Imbalance)، ابتدا معنى لفظى تعبير مى شود، و معناى مجازى زمانى تعبير مىشود كه تعبير لفظى مناسب

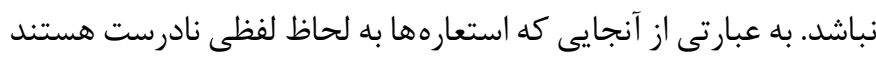
درك استعارهها از تشبيهها كه به لحاظ لفظى درست هستند بايد

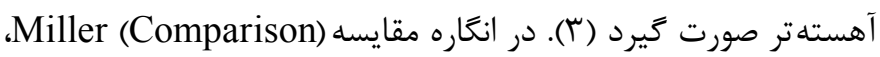
اين فرض مطرح است كه افراد آنجه را مى خوانند درست مى يندارند (1). استعارههايى كه به لحاظ لفظى نادرست يا بى معنى هستند براى نظام مفهومى خواننده مشكل ايجاد مى كنند، جون استعارهها از فرضيه درستى تخطى مى كنند. اين باعث فشار به ذهن خواننده مىشود براى حل اين مشكل خواننده اين مقايسهها را به تشبيه تغيير مى دهند كه جنين فشارى را موجب نمىشود (ه). انگاره مقولهبندى (Categorization) شاخصترين انغاره در رويكرد مستقيه در يردازش استعاره به شمار مىرود. انگاره مقولهبندى يردازش

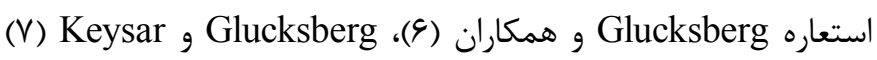
يردازش استعاره را تابع سه اصل مى داند. اول آن كه معانى لفظى خودكار

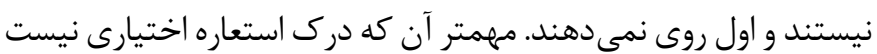
و درك آن به ناقص بودن معانى لفظى بستخى ندارد. در عوض درى دوى استعاره اجباريست يعنى خود كار است. دوم، استعارهها به ندرت از طريق مقايسه فهميده مىشوند در عوض آنها به صورت عبارت شمول_طبقه فهميده مىشوند. سوم، استعارهها عبارتهاى (Class-inclusion) شمول_مقولهاى هستند. در مورد استعارههاى متعارف اين مقوله از قبل

وجود دارد، اما در مورد استعارههاى بديع يك مقوله خلق مىشود (V).

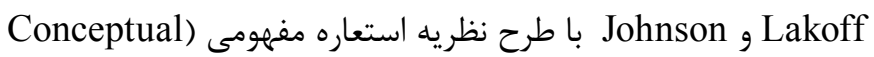
تبيينى از نحوه درى عبارتهاى غيرلفظى (metaphor theory از جمله استعاره بدست دادند (N). به باور آنها عبارتهاى استعارى در واقع صورت تجلىيافته مكانيسم مفهوى زير ساختى ذهن به نام استعاره مفهومى كه ابزارى براى تفكر و همرجنين گفتار است، هستند. به عنوان مثال عبارت استعارى "به نظرات ما در جلسه حمله شد". تظاهر 
ندارد. اين نتيجه با نظريه دو مرحلهاى در تقابل قرار داشت (1) (1). Harris

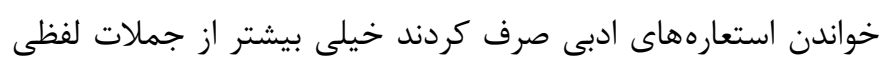

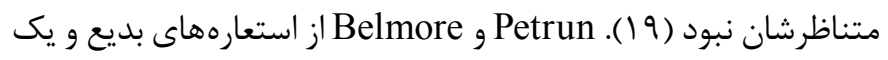



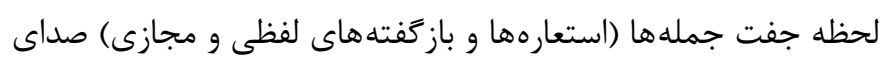

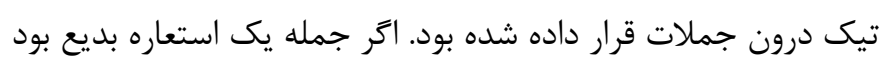

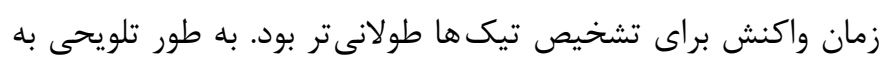

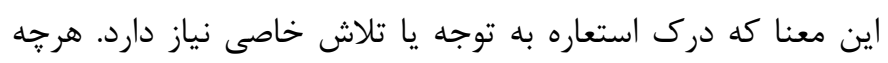

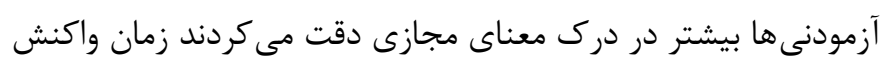

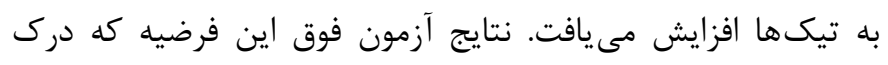

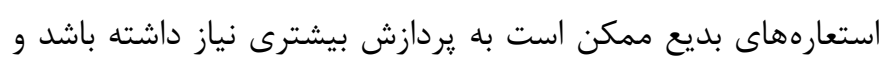

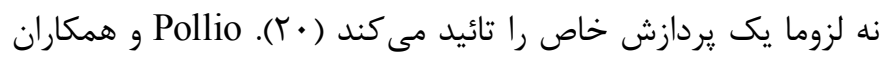

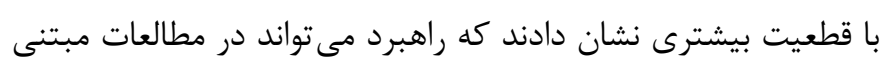

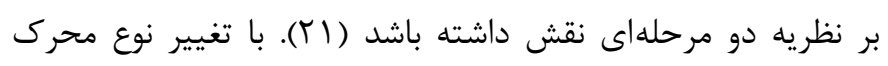

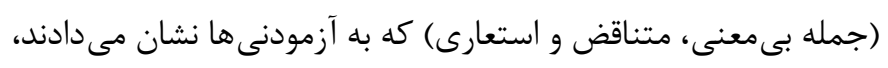

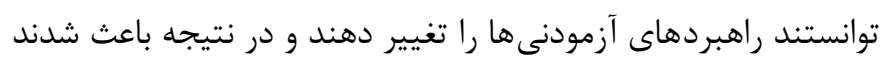

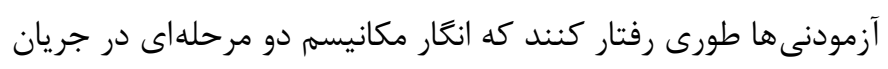

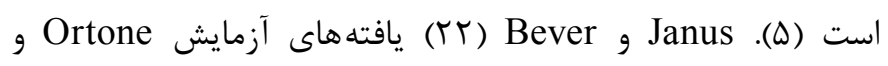

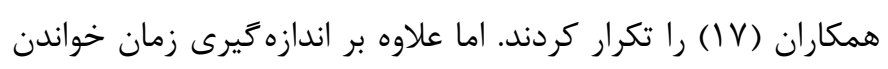

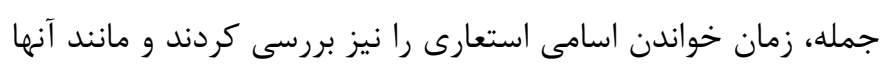

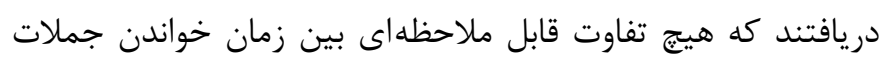

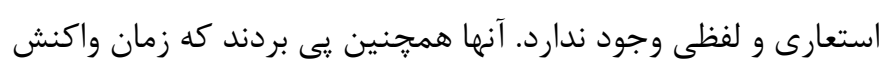

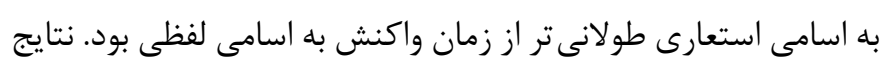

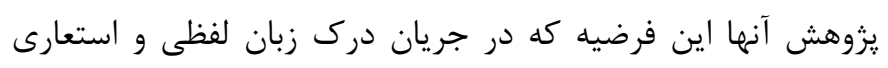

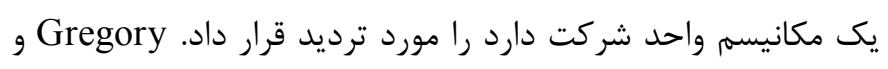

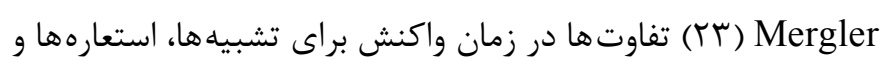

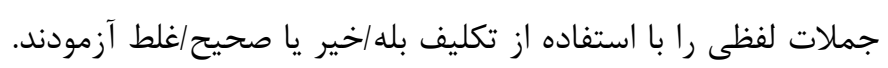

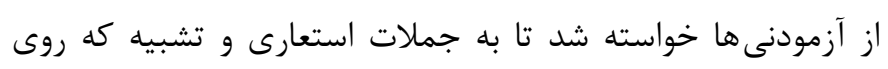

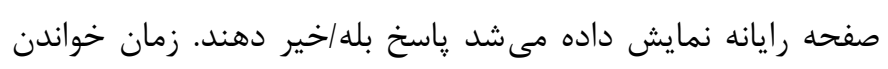

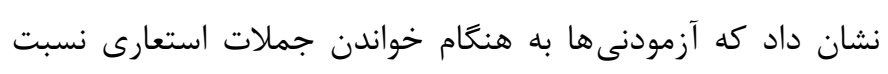

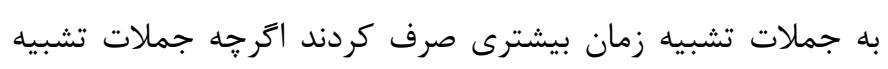

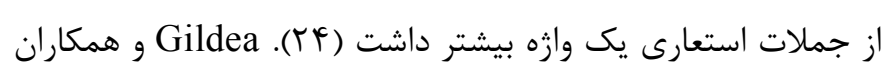

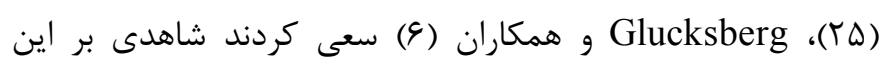

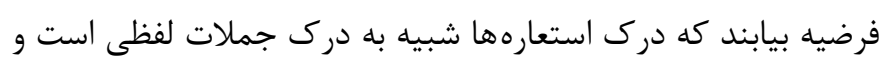

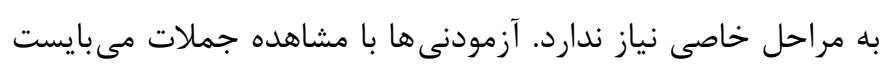

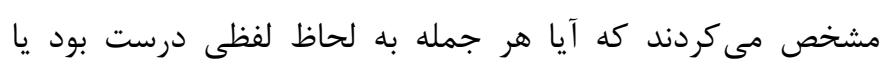

كه خواندن سناريوى حاوى عبارتهاى استعارى بازنمايى حوزه مبدا

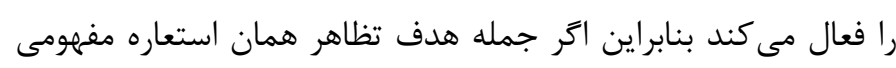

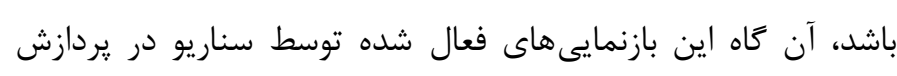

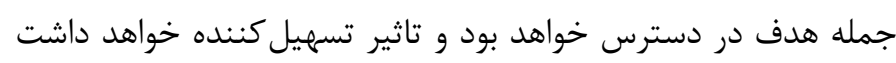

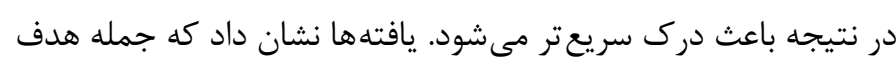

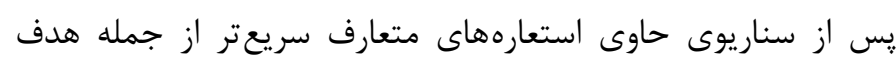

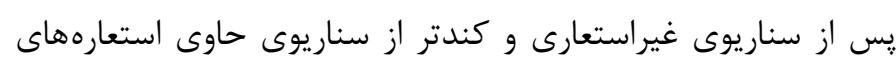

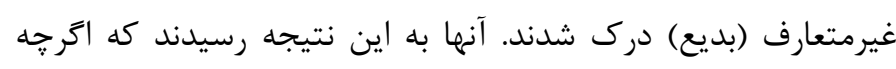

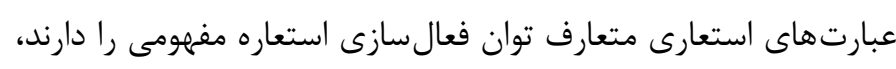

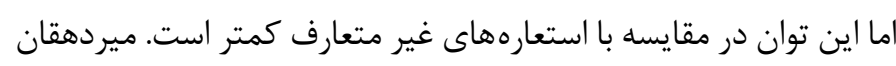

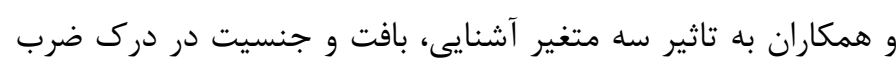

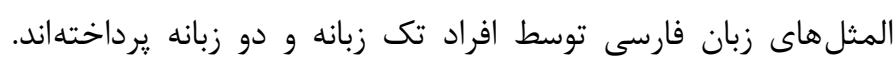

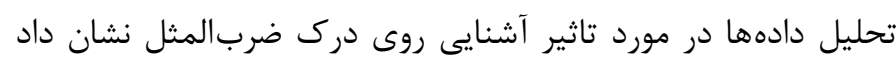

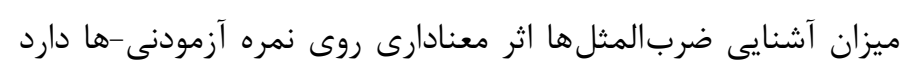

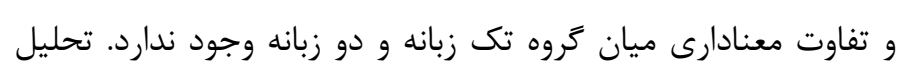

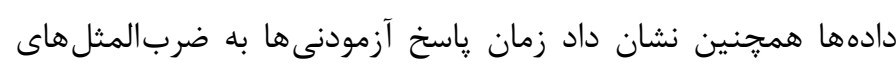

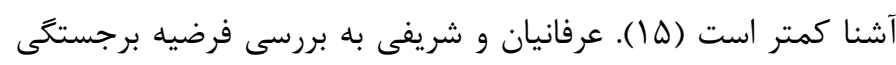

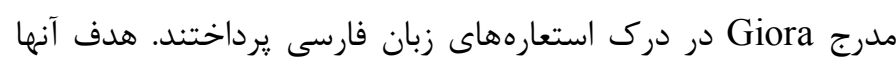

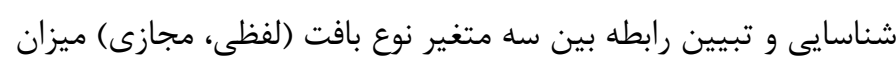

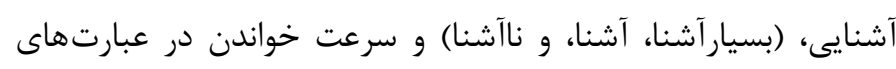

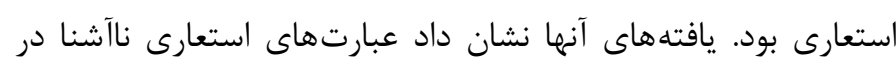

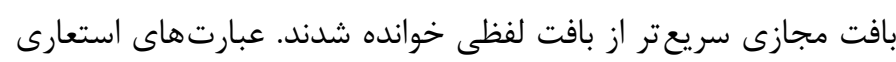

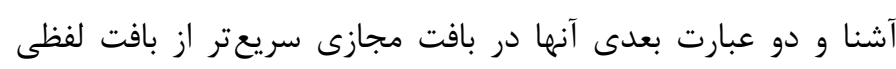

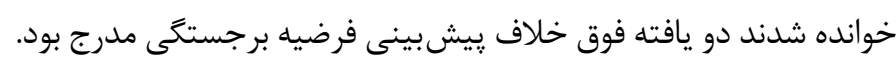

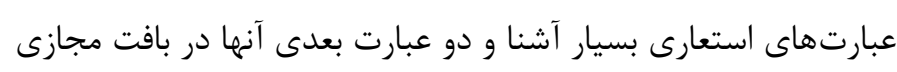
كندتر از بافت لفظى خوانده شدند و اين مطابق با بيش بيش بينى فرضيه

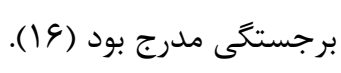

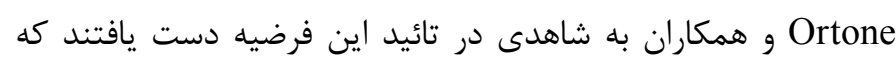

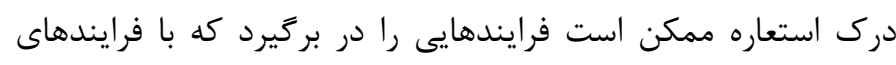

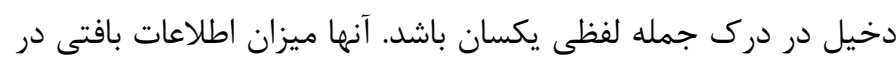

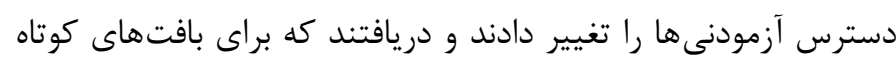

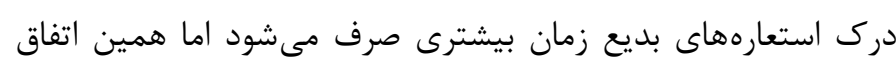

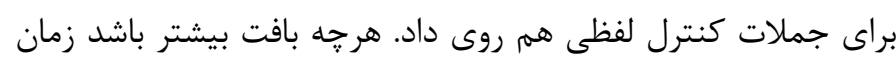

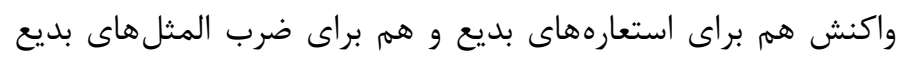

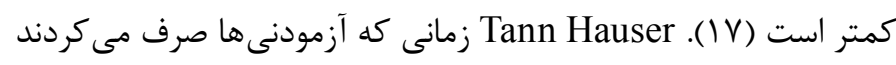

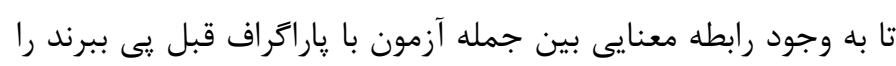

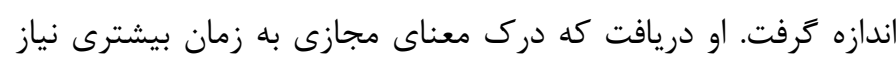


درك تشبيه ها بيشتر خواهد بود هون خواننده بايستى جمله را به عنوان

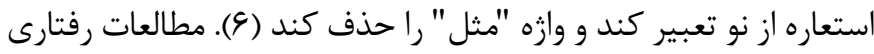
زمان واكنش در مورد شيوه درك استعاره عمدتا در رد يا تائيد يكى از

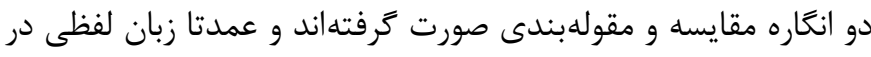

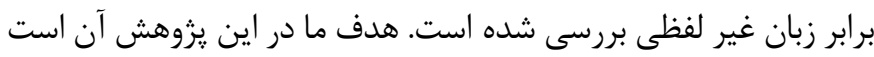

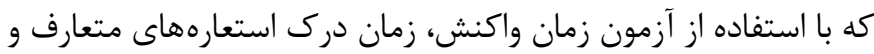

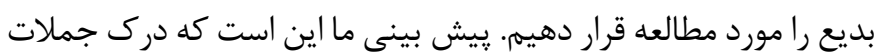
ستعارى بديع نسبت به جملات استعارى متعارف كندتر صورت مى گيرد و درى جملات استعارى متعارف و جملات لفظى همزمان روى مى دهد. اين كزارش بخشى از يك مطالعه بزركتر است كه به منظور بررسى

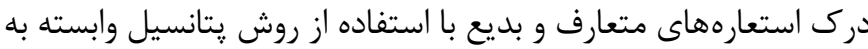
رويداد (Event Related Potential (ERP) انجام شده است. در اين مقاله يافتهاى رفتارى كزارش شده است.

\section{ورش كار}

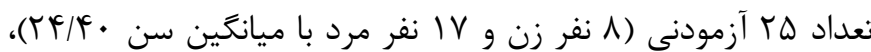
از موسسه آموزش عالى علوم شناختى در آزمون زمان واكنش شركت كردند. همكى راست دست بودند و هيجگدام اختلال عصبى يا آسيبهاى مربوط به سر كه يك اثر جانبى طولانى مدت داشته باشد

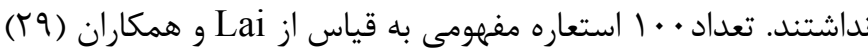
ز صفحه خانكى استعاره مفهومى Lakoff انتخاب شد. با توجه به وازثه

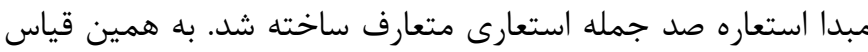
صد جمله استعارى بديع، صد جمله لفظى و صد جمله بىمعنى نيز

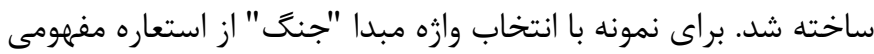
"بحث جنَ است"، ابتدا جمله استعارى متعارف ساخته شد. سِّ جملات استعارى بديع، جملات لفظى و جملات بىمعنى به قياس از

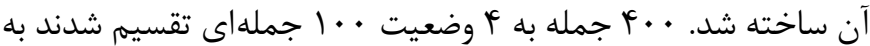

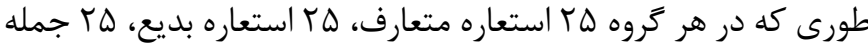

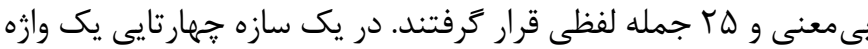
هدف پايانى در تمام وضعيتهاى لفظى، متعارف، بديع، و بى معنى مورد

$$
\text { استفاده قرار مى كرفت (جدول دمام وضعيت ). }
$$

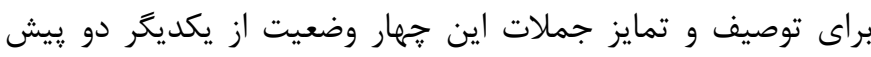

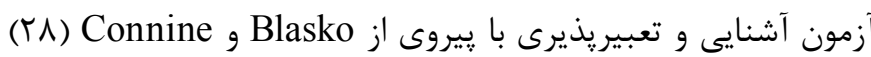

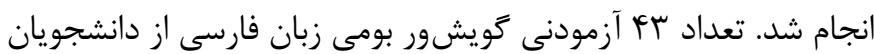
دانشكاه مازندران در اين آزمون شركت كردند. يك وازّه هدف بايانى در تمام وضعيتهاى لفظى، متعارف، بديع، و بىمعنى مورد استفاده قرار

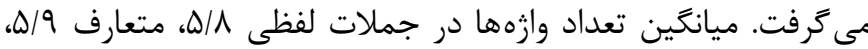

نادرست. (يك تكليف آزمون انتخاب طبقهبندى) برخى از اين جملات به لحاظ لفظى نادرست بودند. برخى از اين جملات به لحاظ لفظى

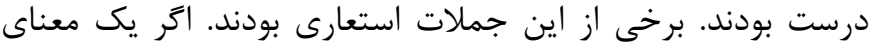
مجازى در دسترس باشد درك آن اجتنابنايذير است، بنابراين

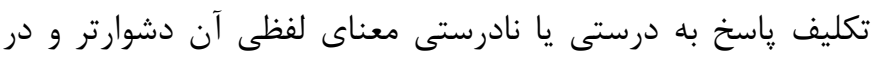

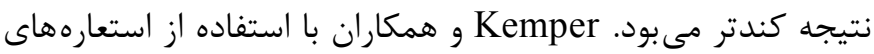

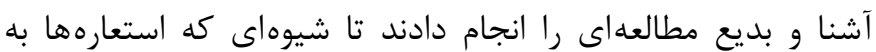
لحاظ مفهومى با متون نثر ييرامونشان انطباق ويدا مى كنند را نشان دهند. زمان درك استعارهها اندازه كرفته شد، وقتى كه مرجع استعاره واضح بود هم درك استعارههاى بديع و هم درك استعارههاى آشنا سريعتر روى داد (ع)). پاسخ به سوالات درباره استعارههاى آشنا يا استعارههايى كه به آسانى تعبير مىشوند سريعتر از باسخ به سوالات

درباره عبارت هاى باز گفته لفظى بود (ه). Inhoff

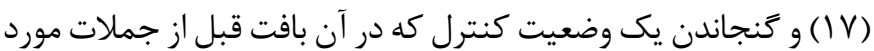
نظر نه به تعبير لفظى ارتباط يِدا مى كرد نه به تعبير مجازى، با استفاده از رديابى جشم سعى كردند زمانى كه آزمودنى ها صرف خواندن جملات مى كنند را اندازه بخيرند. نتايج تحقيق آنها همان نتايج Ortone و همكاران مبنى بر اين كه استعارهها يِ از بافتهاى طولانى تر همزمان با جملات لفظى درك مىشوند را تكرار كرد (IV). در مورد بافت كوتاه بين زمان خواندن جملاتى كه مجازى در نظر كرفته مى شدند (جملات استعارى) و جملاتى كه يس از بافت غيرمرتبط مى آمدند (لفظى) تفاوتى وجود نداشت. آنها نتيجه كيرى كردند كه استعارهها يا به طور

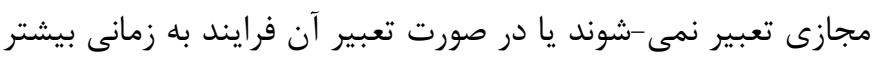

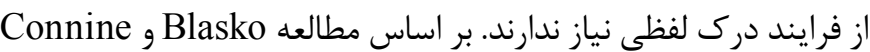
استعارههاى بسيار آشنا دسترسى به معناى مجازى را نشان دادند. اما استعارههاى كمتر آشنا دسترسى به معناى مجازى را نشان ندادند. استعارههاى كمتر آشنا اما بسيار مناسب شاهدى از فعالسازى معنى مجازى را نشان دادند. به باور آنها استعارههاى بديع مى توانند همزمان

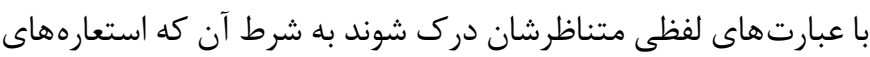
بديع مناسب باشند (همانجا) (T).

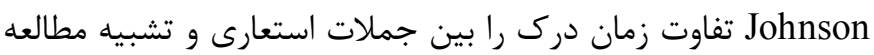
نمود. بر اساس نظريه دو مرحلهاى جملاتى كه معناى لفظى دارند (لفظى و تشبيه) سريعتر يردازش مىشوند، اما يافتههاى او جنين نظريهاى را تائيد نكرد (TY). در مقابل طبق نظريه شمول_طبقه Glucksberg به خاطر وجود رابطه شمول_طبقه بين عناصر در يك جمله جملات استعارى بايستى سريعتر از تشبيه ها يردازش شوند. زمان 
هزارم ثانيه روى صفحه نمايش داده مىشد. فاصله زمانى بين دو وازه به طول وازه بستخى داشت: . . هزارم ثانيه به علاوه rV هزارم ثانيه به ازاى هر حرف در وازه قبلى نشان داده مىشد. يس از وازّه هدف يايانى يك صفحه سياه به مدت • • • هزارم ثانيه قبل از ظاهر شدن علامت سوال نمايش داده مىشد. يس از ديدن علامت سوال آزمون شوندهها با فشار دادن يكى از

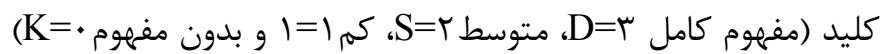
روى صفحه كليد نشان مى دادند آن جمله در زبان فارسى جه مقدار مفهوم به همراه دارد. يس از ير كردن فرم رضايت آكاهانه، توضيحات مختصرى در مورد نحوه اجراى آزمون به آزمودنى ها داده شد. آزمون در يك اتاق آرام با نور ملايم انجام گرفت. نصب شبكه حسگرهاى دستخاه Electroencephalogram حدود •r دقيقه طول مى كشيد، كه شامل حذاشتن شبكه روى سر آزمودىها، قراردادن حسگرها و تنظيم آنها براى رسيدن به سطح مطلوب مقاومت ظاهرى كمتر از • F اهم را شامل مى شد. در نهايت تكليف اصلى توسط نرمفزار ثبت سيخنال EEGLAB ثبت شد. آزمودنى ها با انخشتهاى اشاره و وسط هر دو دست ياسخ مى دادند. هر گاه ياسخ داده مى شد برنامه به مرحله بعد مىرفت (نتايج سيخنال هاى مغزى در مقالهاى جداكانه ارائه خواهد شد). دادهاى مربوط به سنجش آشنايى و تعبيريذيرى محركها (f) وضعيت) و دادههاى زمان راسخ با استفاده از تحليل واريانس با اندازه گيرى مكرر و مقايسه دو سويه دادهها در جهار وضعيت با استفاده از نرمافزار آمارى SPSS-22 مورد تجزيه و تحليل قرار گرفت. در تمام تحليل ها از سطح معنادارى ه • P P استفاده گرديد.

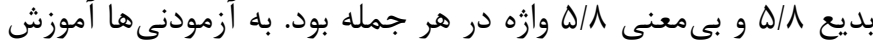
داده شد تا ميزان آشنايى و سيس ميزان تعبيريذيرى هر جمله را در مقياس • تا س مشخص نمايند. دستورالعمل براى تعيين ميزان آشنايى از اين قرار است: اگر عبارتهاى مشابهى را از قبل بارها شنيدهايد

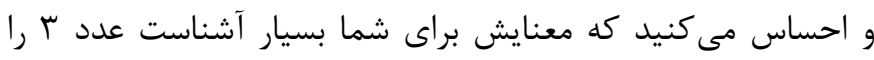
انتخاب كنيد. اءر عبارتهاى مشابهى را از قبل جندبار شنيدهايد و

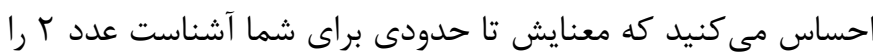
انتخاب كنيد. اخر عبارتهاى مشابهى را از قبل يكى يا دو بار شنيدهايد و احساس مى كنيد كه معنايش تا حدودى براى شما آشناست عدد | رانتخاب كنيد. اگر جنين عبارتهايى را از قبل نشنيدهايد و احساس مى كنيد كه معنايش براى شما ناآشناست عدد • را انتخاب كنيد. دستورالعمل براى تعيين ميزان تعبيريذيرى از اين قرار است: اگر احساس مى كنيد كه جمله به آسانى قابل تفسير است عدد ب را انتخاب كنيد. اگر تعبير جمله مدت زمان كوتاهى طول كشيد عدد ؟ را انتخاب كنيد. اگر تعبير جمله مدت زمان زيادى طول كشيد عدد ا را انتخاب كنيد. اگر به تعبيرى از جمله نرسيديد عدد •را انتخاب كنيد. يافته هاى اين دو ييش آزمون نشان داد كه جملات لفظى بسيار آشنا و بسيار تعبيريذيرند. استعاره متعارف هم بسيار آشنا و بسيار تعبيريذيرند، اما ميزان آشنايى و تعبيريذيرى استعاره متعارف اندكى كمتر از جملات لفظى است. استعاره بديع استعاره ايست ناآشنا و تعبير آن دشوارتر است و جملات بىمعنى هم ناآشنا و هم تعبيرنايذيرند. تكليف نمايش وازمها در اين جهار وضعيت بر اساس يزوهش Coulson

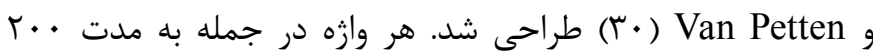

\begin{tabular}{|c|c|c|c|}
\hline هدف & 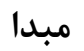 & جملات & نوع جمله \\
\hline جنَ & جنَ & به مواضع دشمن در جنَ حمله شد. & لفظى \\
\hline بحث & جنَ & به نظرات ما در جلسه حمله شد. & استعارى متعارف \\
\hline توهين & جنَ & به شعور مردم حمله شد. & استعارى بديع \\
\hline توهين & جنَ & به ادب صندلى حمله شد. & بى معنى \\
\hline
\end{tabular}


استعارههاى متعارف آشناتر و تعبيريذيرتر بودند. استعارههاى بديع از آشنايى كمتر برخوردار بودند اما در عين حال همجنان تعبيريذيرتر بودند. رابطه بين متغيرهاى آشنايى و تعبيريذيرى در وضعيت جملات لفظى، استعاره متعارف، استعاره بديع و جملات بىمعنى رابطه معنادارى بود.

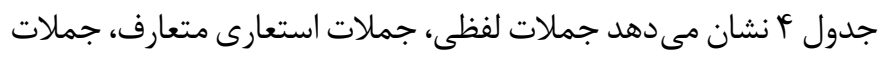

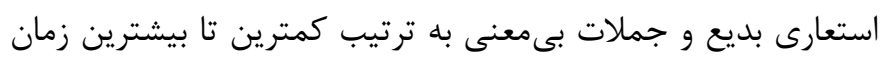

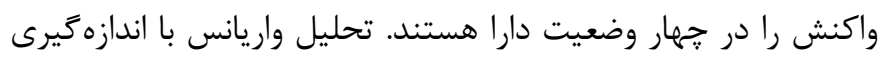
مكرر تائيد كرد كه تفاوت معنادارى به لحاظ ميزان زمان واكنش بين

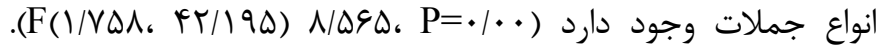
مقايسه دوسويه نشان داد بين استعارههاى متعارف و جملات لفظى

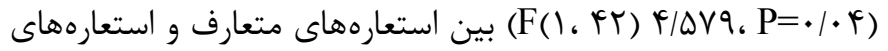

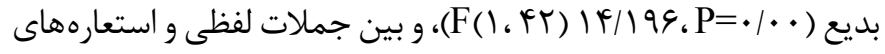

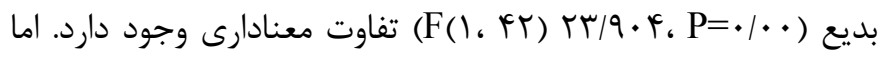

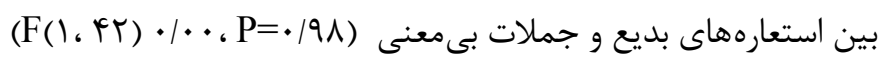
تفاوت قابل ملاحظهاى وجود ندارد.

جدول r. ميانگين و انحراف معيار آشنايى (تعداد آزمودنىها بَ نفر)

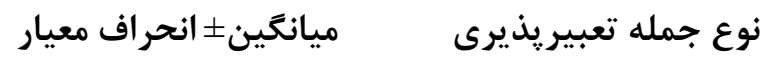

\begin{tabular}{|c|c|}
\hline$\cdot|| r \mid \cdot r \pm r / \Lambda r \cdot q$ & لفظى ل لفى \\
\hline$\cdot / 1 \Delta q 4 F \pm r / \varepsilon r q q$ & استعارى متعارف \\
\hline$\cdot / 19 \Lambda 1 r \pm r / \cdot \| 1 r$ & استعارى بديع \\
\hline$\cdot / 1 \wedge \varepsilon \Delta \Delta \pm \cdot / \cdot \Delta \mid 91$ & بى معنى \\
\hline
\end{tabular}

جدول F. ميانكَين و انحراف معيار آشنايى (تعداد آزمودنىها ه؟ نفر )

\begin{tabular}{|c|c|}
\hline ميانگين \انحراف معيار & نوع جمله \\
\hline$\cdot / 1 \Delta \cdot r \Delta \pm r / q \uparrow q$. & لفظى \\
\hline . /IFTRGET/ITRI & استعارى متعارف \\
\hline$. / 19941 \pm 1 / r \cdot r \cdot$ & استعارى بديع \\
\hline$\cdot / 1 \wedge 9 \Delta \cdot \pm \cdot / \mu \mid \& 4$ & بى معنى \\
\hline
\end{tabular}

يافته ها

جدول r نشان مى دهد جملات لفظى، جملات استعارى متعارف،

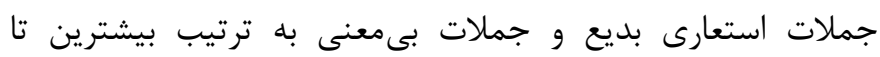

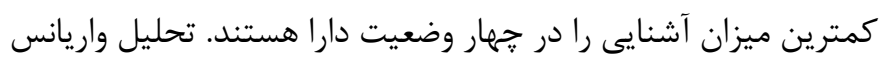
با اندازهزيرى مكرر تائيد كرد كه ميزان آشنايى تفاوت معنادارى را بين دانين

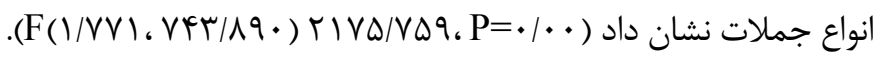
مقايسه دوسويه نيز تفاوت معنادارى را بين استعارههاى متعارف وجملات

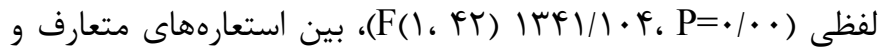

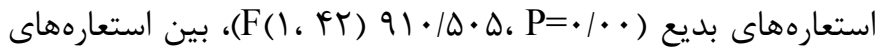

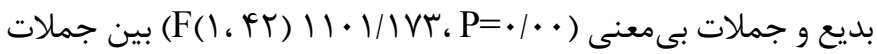

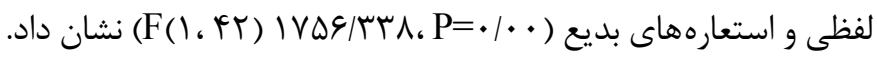

جدول r. ميانكَين و انحراف معيار آشنايى (تعداد آزمودنى ها بع نفر)

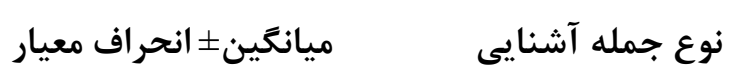

\begin{tabular}{|c|c|}
\hline$\cdot / / \Delta \cdot r \Delta \pm r / \varepsilon r q$. & لفظى \\
\hline - IFrTSET/ITVI & استعارى متعارف \\
\hline$\cdot / 19941 \pm 1 / r \cdot r \cdot$ & استعارى بديع \\
\hline$\cdot / 1 \wedge 9 \Delta \cdot \pm \cdot / T_{1} \& 4$ & بى معنى \\
\hline
\end{tabular}

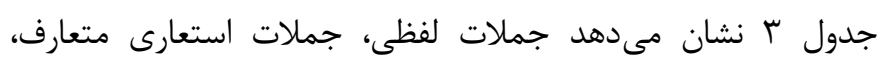

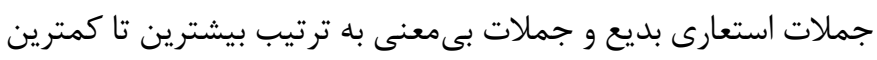

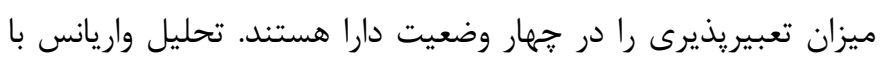

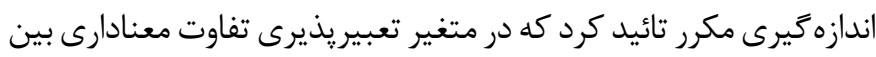

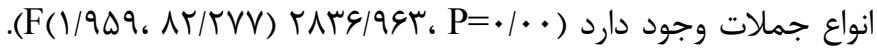
مقايسه دوسويه نيز تفاوت معنادارى را بين استعارههاى متعارف و جملات

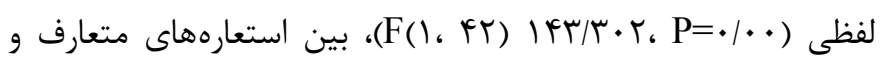

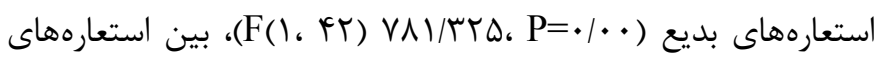

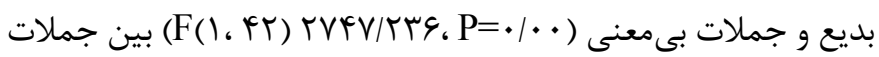

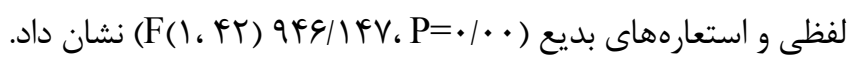

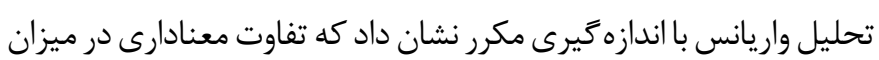

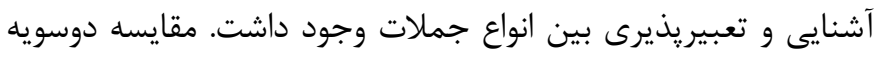

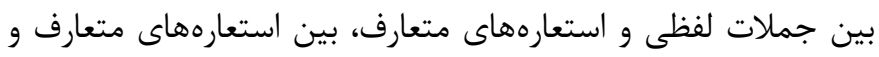

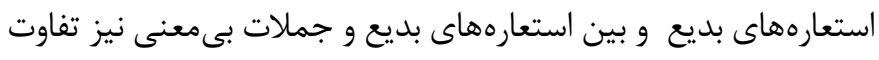

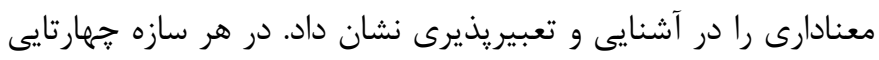




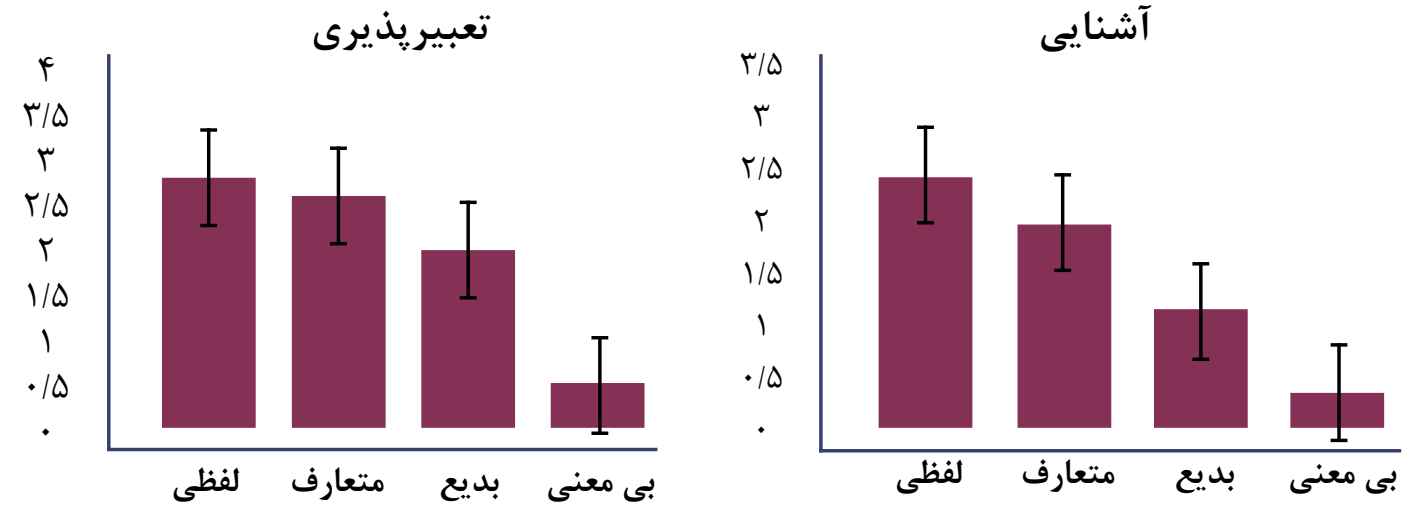

نمودار ا. ميزان آشنايى (سمت راست) و ميزان تعبيريذيرى (سمت جٍ) براى جملات لفظى، استعارى متعارف، استعارى بديع و بىمعنى

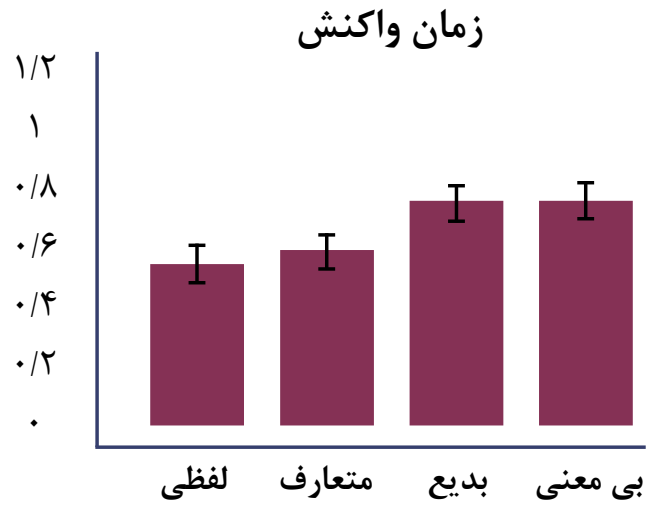

نمودار r. زمان واكنش بر حسب ثانيه

طريق مقولهبندى درك مىشوند. Lakoff معتقد است جملات لفظى و استعارههاى متعارف هر دو از حافظه فراخوانده مىشوند به همين دليل يردازش يكسانى دارند (9). در حالى كه يافتهها يثوهش ما نشان داد جملات لفظى سريعتر از جملات استعارى متعارف درى شدند. Giora علت اين يردازش يكسان جملات لفظى و استعارهها را در اين مى داند كه هر دو به يك اندازه برجستهاند. ييش آزمون آشنايى نشان داد استعارههاى بديع نآشناتر از جملات لفظى بـ و استعارى متعارف هستند، از طرفى يافته دوم تكليف زمان واكنش نشان داد استعارههاى بديع كندتر از جملات لفظى و استعارى متعارف درك مى شوند. به عبارت ديكر درك استعارههاى بديع در مقايسه با استعارههاى متعارف به زمان و تلاش بيشترى نياز دارد. اين يافته شاهدى در تائيد نظريه استعاره مفهومى Lakoff و Johnson (N)، نظريه معاصر

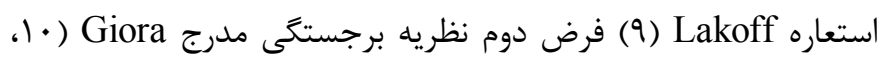

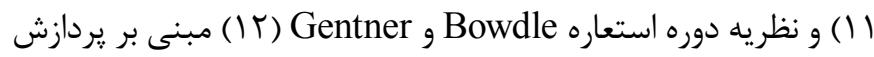
طولانى تر استعارههاى بديع نسبت به جملات لفظى و استعاره متعارف است. بر اساس نظريه استعاره مفهومى اين زمان واكنش بيشتر و تلاش
از آنجايى كه ييش آزمون آشنايى نشان داد جملات لفظى از جملات استعارى متعارف آشناتر هستند، از طرفى يافته نخست تكليف زمان واكنش نشان داد جملات لفظى سريعتر از جملات استعارى متعارف درك مىشوند. يافته فوق با نظريه كاربردشناسى معيار Grice (1) و Searle گردد، آر معنى لفظى مناسب نبود جستجو براى ساخت معنى استعارى آغاز شود همسو است. همجنين با نظريه استعاره مفهومى Lakoff و كه ييشنهاد مى كند كه معانى استعارى ابتدا با دسترسى Johnson به معانى لفظى و نگاشت دادن آن معانى از يك حوزه به حوزه ديگر درك مى ديگر مستلزم صرف زمان اضافى در مقايسه با معنى لفظى است. يافته فوق با انگاره مقولهبندى Glucksberg، نظريه معاصر استعاره Lakoff (9) و با فرض نخست انغاره برجستخى مدرج Giora (• (1 (1) در تقابل

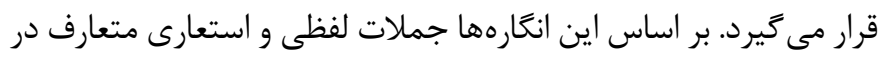
يك زمان يكسان زيردازش مىشوند. Glucksberg دليل اين يردازش يكسان را در اين مىداند كه جملات لفظى و استعارههاى متعارف از 
متعارف سريعتر از جملات استعارى بديع درك مىشوند. البته شايان ذكر است تفاوت سرعت درك بين جملات لفظى و استعارى متعارف

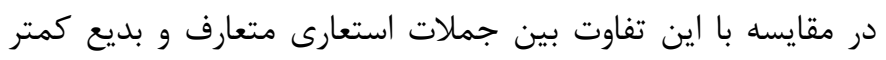

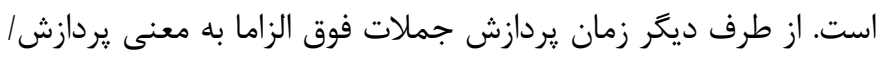

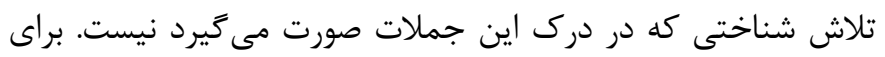

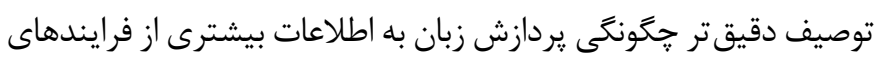

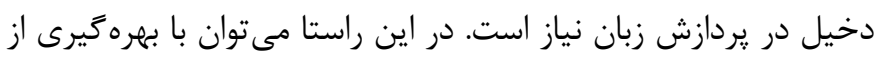
روشهاى تصويربردارى نقشى مغز مانند ثبت يتانسيل وابسته به رويداد تغييرات لحظه به لحظه در فعاليت الكتريكى مغز كه از وضوح زمانى بسيار بالايى برخوردار است، شواهد محكمترى از جگتونكى يردازش زبان

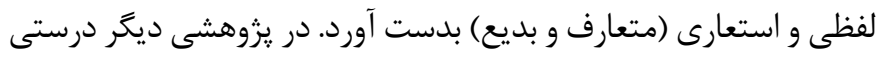

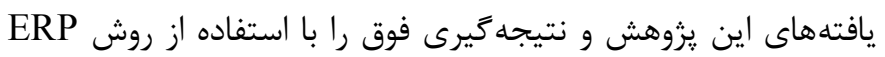
بررسى خواهيم كرد.

\section{نتيجه كَيرى}

با توجه به يافته هاى فوق مى توان نتيجه كرفت كه مكانيسمهاى متفاوتى در يردازش زبان لفظى و استعارى شركت دارند. يردازش استعارههاى

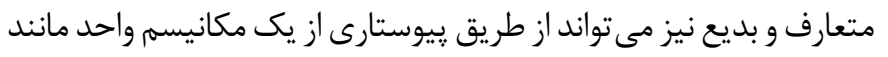

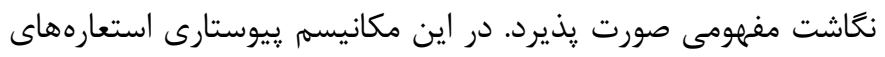

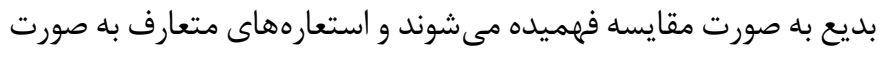

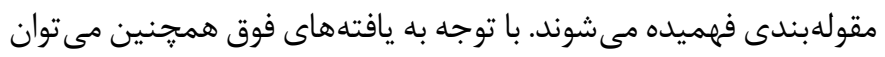

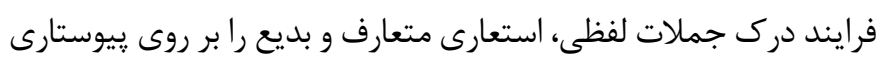
از برجستخى و قابل انتظار بودن تبيين كرد.

\section{تشكر و قدردانى}

الز همكارى موسسه آموزش عالى علوم شناختى در انجام اين يزوهش سياس كذارى مى نمائيم.

\section{References}

1. Grice H. Logic and conversation. In: Cole P, Morgan J, editors. Speech acts. Leiden:Brill;1975. pp. 41-58.

2. Searle J. Metaphor. In Ortony A, editor. Metaphor and thought. New York:Cambridge University Press;1979. pp. 92-123.

3. Ortony A. Beyond literal similarity. Psychological Review. 1979;86(3):161-180.

4. Miller, G. A. Images and models, similes and metaphors. In
شناختى بيشتر را مىتوان ناشى از نكاشت يك حوزه مفهومى بر حوزه

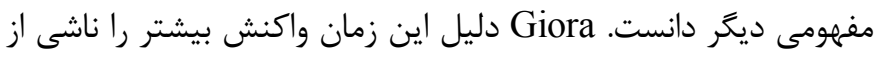

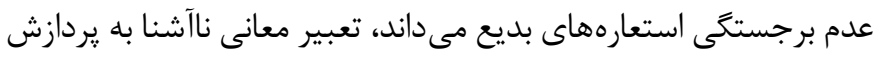

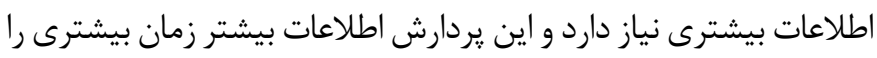

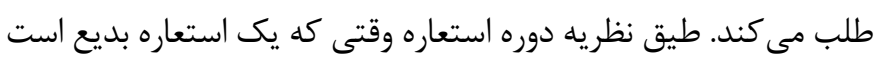
به صورت مقايسه فهميده مىشود و وقتى كه متعارف مى شود به صورت مقولهبندى فهميده مىشود. يردازش معنى از طريق مقايسه نسبت بـ به وفيه مقولهبندى به زمان بيشترى نياز دارد. يافته فوق همجنين يافتههاى

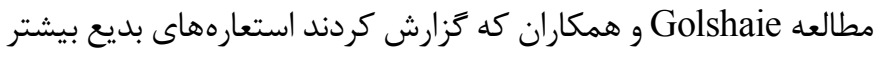
از استعارههاى متعارف توان فعال سازى استعارههاى مفهومى را دارند و

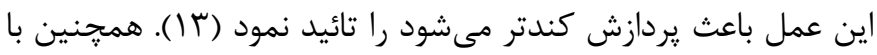

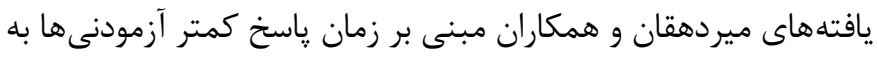

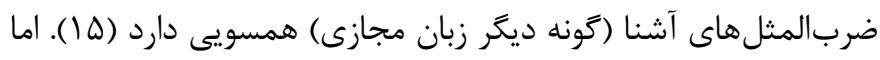

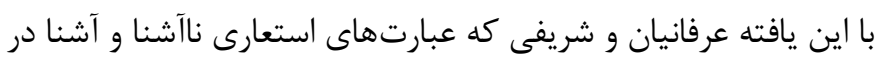

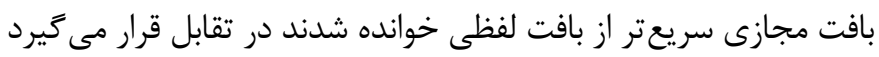

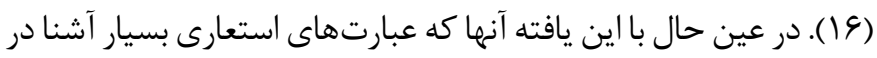
بافت مجازى كندتر از بافت لفظى خوانده شدند همسويى دارد. به علاوه يافتهاى يزوهش حاضر با يافته هاى يزوهش هاى Petrun و Belmore

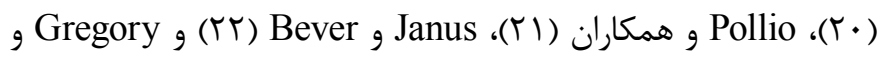
Mergler

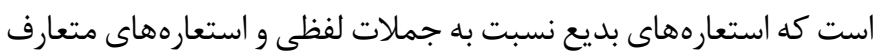

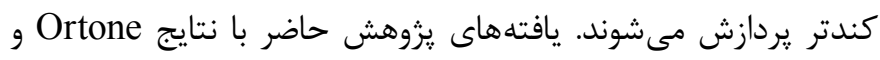

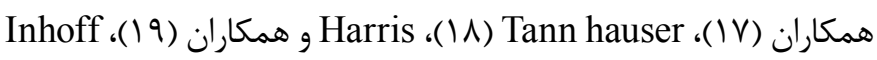

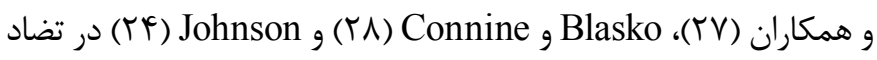

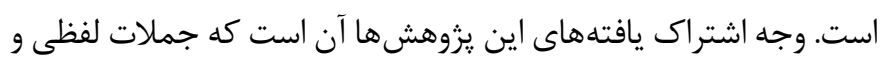

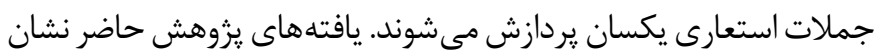

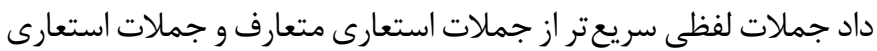

Ortony A, editor. Metaphor and thought. New York:Cambridge University Press;1979. pp. 202-250.

5. Hoffman RR, Kemper S. What could reaction-time studies be telling us about metaphor comprehension?. Metaphor and Symbol. 1987;2(3):149-186.

6. Glucksberg S, Gildea P, Bookin HB. On understanding nonliteral speech: Can people ignore metaphors?. Journal of Ver- 
bal Learning and Verbal Behavior. 1982;21(1):85-98.

7. Glucksberg S, Keysar B. Understanding metaphorical comparisons: Beyond similarity. Psychological Review. 1990;97(1):3-18.

8. Lakoff G, Johnson M. Metaphors we live by. Chicago:University of Chicago Press; 1980.

9. Lakoff G. The contemporary theory of metaphor. In: Ortony A, editor. Metaphor and Thought. 2nd ed. Cambridge:Cambridge University Press; 1993.

10. Giora R. Understanding figurative and literal language: The graded salience hypothesis. Cognitive Linguistics (Includes Cognitive Linguistic Bibliography). 1997;8(3):183-206.

11. Giora R. On our Mind: Salience, context, and figurative language. New York:Oxford University Press;2003.

12. Bowdle BF, Gentner D. The career of metaphor. Psychological Review. 2005;112(1):193-216.

13. Golshaie R. A corpus-based evaluation of conceptual metaphor theory's assumptions: The case of "RGUMENT IS WAR" Metaphor in Persian [PhD Dissertation]. Tehran:Tarbiat Modares University;2012. (Persian)

14. Keysar B, Shen Y, Glucksberg S, Horton WS. Conventional language: How metaphorical is it?. Journal of Memory and Language. 2000;43(4):576-593.

15. Mirdehghan M, Nejati V, Davoodi E. A comprehensive study of Persian proverbs among monolingual and bilingual adolescents comparatively on the basis of the constraint satisfaction model. Language Related Research. 2012;3(3):193216. (Persian)

16. Erfanian L, Sharifi Sh. Metaphor; A survey on the factors related to semantic comprehension; their effectiveness and psychological reliability. Journal of Language Research. 2014;5(2):97-112. (Persian)

17. Ortony A, Schallert DL, Reynolds RE, Antos SJ. Interpreting metaphors and idioms: Some effects of context on comprehension. Journal of Verbal Learning and Verbal Behavior. 1978;17(4):465-477.

18. Tann Hauser S. Levels of interpretation: A study of metaphor-literal differences. In Meeting of the Midwestern Psycho- logical Association. Chicago;1978.

19. Harris RJ. Comprehension of metaphors: A test of the twostage processing model. Bulletin of the Psychonomic Society. 1976;8(4):312-314.

20. Petrun C, Belmore S. Metaphor comprehension and cognitive effort. In the Annual Meeting of the American Psychological Association. New York; 1981.

21. Pollio H, Fabrizi M, Sills A, Smith MIs. Metaphor comprehension a derived process?. Knoxville:University of Tennessee, Department of Psychology;1982.

22. Janus RA, Bever TG. Processing of metaphoric language: An investigation of the three-stage model of metaphor comprehension. Journal of Psycholinguistic Research. 1985;14(5):473-487.

23. Gregory ME, Mergler NL. Metaphor comprehension: In search of literal truth, possible sense, and metaphoricity. Metaphor and Symbol. 1990;5(3):151-173.

24. Johnson AT. Comprehension of metaphors and similes: A reaction time study. Metaphor and Symbol. 1996;11(2):145-159. 25. Gildea P, Glucksberg S, Bookin H. Turning bad metaphors into good: Literal activation of figurative meaning. In the meeting of the Eastern Psychological Association. New York;1981. 26. Kemper S, Hine J, Ambler M. Comprehending the implications of metaphors. Manhattan:University of Kansas, Department of Psychology; 1984.

27. Inhoff AW, Lima SD, Carroll PJ. Contextual effects on metaphor comprehension in reading. Memory \& Cognition. 1984;12(6):558-567.

28. Blasko DG, Connine CM. Effects of familiarity and aptness on metaphor processing. Journal of Experimental Psychology: Learning, Memory, and Cognition. 1993;19(2):295-308.

29. Lai VT, Curran T, Menn L. Comprehending conventional and novel metaphors: An ERP study. Brain Research. 2009;1284:145-155.

30. Coulson S, Van Petten C. Conceptual integration and metaphor: An event-related potential study. Memory \& Cognition. 2002;30(6):958-968. 